\title{
PENGARUH MEDITASI TERHADAP HIPERTENSI PADA LANSIA DI BANJAR ANGKLING DESA BAKBAKAN WILAYAH KERJA PUSKESMAS GIANYAR II
}

\author{
THE EFFECT OF MEDITATION ON \\ HYPERTENSION IN THE ELDERLY IN BANJAR \\ ANGKLING BAKBAKAN VILLAGE, GIANYAR II \\ PUBLIC HEALTH CENTER
}

\author{
Ni Putu Wiwik Oktaviani ${ }^{1}$, Ni Putu Yessi Urmilasari², Ni Wayan Trisnadewi ${ }^{3}$, I Made \\ Sudarma Adiputra ${ }^{4}$ \\ Sekolah Tinggi Ilmu Kesehatan Wira Medika Bali ${ }^{1,2,3,4}$ \\ Program Studi S3 Ilmu Kedokteran Universitas Udayana ${ }^{3,4}$ \\ Rumah Sakit Umum Pusat Sanglah ${ }^{2}$
}

\begin{abstract}
ABSTRAK
Introduction: Hipertensi adalah masalah yang paling sering terjadi pada kesehatan lansia dan menjadi penyebab utama penyakit kardiovaskular pada lansia. Meditasi digunakan sebagai upaya penangan hipertensi dengan mengontrol kontriksi dan merelaksasi pembuluh darah yang terletak pada pusat vasomotor di medula spinalis serta sebagai latihan relaksasi meditasi yang dapat menurunkan hipertensi. Tujuan penelitian ini untuk mengetahui pengaruh pemberian meditasi terhadap hipertensi pada lansia. Method: Jenis penelitian pra eksperimental dengan rancangan One group Pre test-posttest Design. Jumlah sampel 20 orang dipilih dengan teknik purposive sampling. Alat yang digunakan mengumpulkan data adalah sphygmomanometer dan stetoskop. Result: Hasil uji statistik Paired $t$ Test menunjukkan ada pengaruh pemberian meditasi terhadap hipertensi pada lansia. Discussion: relaksasi meditasi yang berfokuskan pada pernafasan akan meningkatkan sirkulasi oksigen ke otot-otot, sehingga otot-otot akan mengendur, tekanan darah akan menurun.
\end{abstract}

Kata kunci: Meditasi, Hipertensi, Lansia

\begin{abstract}
Introduction: Hypertension is the most common problem in elderly health and is a major cause of cardiovascular disease in the elderly. Meditation is used as an effort to treat hypertension by controlling the relationship and relaxing the blood vessels located in the vasomotor center in the spinal cord and as a relaxation meditation exercise that can reduce hypertension. The purpose of this study was to determine the effect of giving meditation on hypertension in the elderly. Method: This type of pre-experimental research with the design of One group Pre test-posttest Design. The total sample of 20 people was selected by purposive sampling technique. The tools used to collect data are a sphygmomanometer
\end{abstract}


Bali Medika Jurnal.

Vol 8 No 1, 2021: 51-63

DOI: https://doi.org/10.36376/bmj.v8i1

and a stethoscope. Result: The mean systolic blood pressure was $169.25 \mathrm{mmHg}$ and diastole was $101.75 \mathrm{mmHg}$. The result shows the effect of giving meditation on hypertension in the elderly. Discussion: relaxation meditation which is centered on breathing will increase the circulation of oxygen to the muscles, so the muscles will relax, blood pressure will decrease.

Keywords: Meditation, Hypertension, Elderly

\begin{tabular}{ll}
\hline Alamat Korespondensi & : Sekolah Tinggi Ilmu Kesehatan Wira Medika Bali \\
Email & : oktaviani.wiwik@yahoo.com \\
\hline
\end{tabular}

\section{PENDAHULUAN}

Kemajuan ilmu pengetahuan dan teknologi serta perbaikan sosio-ekonomi berdampak pada peningkatan derajat kesehatan masyarakat. Meningkatnya derajat kesehatan masyarakat menyebabkan peningkatan persentase jumlah penduduk lansia (Tamher \& Noorkasiani, 2015). Data profil Kesehatan Indonesia menunjukkan jumlah lansia di Indonesia tahun 2017 mencapai 20,24 juta jiwa, setara dengan 10,77 persen, jumlah lansia meningkat pada tahun 2018 menjadi 24,71 juta jiwa setara dengan 12,77 persen dari seluruh penduduk Indonesia (Kementerian Kesehatan Republik Indonesia, 2018).

Lansia pada umumnya mengalami berbagai kemunduran fungsi organ tubuh sehingga rawan terhadap serangan berbagai penyakit kronis, seperti diabetes melitus, stroke, gagal ginjal, kanker, hipertensi, dan jantung. Adapun jenis keluhan kesehatan yang paling banyak dialami lansia adalah keluhan lainnya, yaitu jenis keluhan kesehatan yang secara khusus memang diderita lansia seperti asam urat, darah tinggi, darah rendah, reumatik, diabetes, dan berbagai jenis penyakit kronis lainnya (Badan Pusat Statistik, 2018). Penyakit terbanyak pada lansia berdasarkan hasil Riset Kesehatan Dasar tahun 2018 adalah hipertensi (57,6\%), artritis (51,9\%), Stroke $(46,1 \%)$, masalah gigi dan mulut $(19,1 \%)$, penyakit paru obstruktif menahun $(8,6 \%)$ dan diabetes mellitus $(4,8 \%)$ (Kementerian Kesehatan Republik Indonesia, 2018).

Hipertensi adalah masalah yang paling sering terjadi pada kesehatan lansia dan menjadi penyebab utama penyakit kardiovaskular pada lansia. Peningkatan umur akan menyebabkan beberapa perubahan fisiologis, pada lansia terjadi peningkatan resistensi perifer dan aktivitas simpatik (Black \& Hawks, 2015). Prevalensi hipertensi pada lansia di Dunia tahun 2018 diperkirakan sekitar 15-20\% sedangkan di Asia diperkirakan sudah mencapai 8-18\%. Hipertensi pada lansia dijumpai pada 4.400 per 10.000 penduduk di Indonesia pada tahun 2018 , penyakit hipertensi pada lansia menempati peringkat pertama dari 10 besar penyakit tidak menular dengan prevalensi $31,7 \%$, arthritis $30,3 \%$, penyakit jantung $7,2 \%$, tumor atau kanker 4,3\%, asma 3,5\%, diabetes melitus $1,1 \%$ dan stroke $0,83 \%$ (Kementerian Kesehatan Republik Indonesia, 2018). Provinsi Bali tahun 2018 menduduki peringkat ke empat dengan kasus hipertensi pada lansia terbanyak di Indonesia, urutan kasus hipertensi pada lansia terbanyak di Indonesia adalah Provinsi Jogyakarta 13,04\%, Jawa Timur 10,4\%, Jawa Tengah 10,2\%, dan Bali 9,78\% (Kementerian Kesehatan Republik Indonesia, 2018). 
Bali Medika Jurnal.

Vol 8 No 1, 2021: 51-63

ISSN : 2615-7047

DOI: https://doi.org/10.36376/bmj.v8i1

Data dari Dinas Kesehatan Provinsi Bali tentang penyakit hipertensi, tercatat jumlah kasus hipertensi pada lansia pada tahun 2016 sebanyak 22.837 kasus, pada tahun 2017 meningkat menjadi 29.867 kasus dan pada tahun 2018 meningkat sebanyak 35.859 kasus (Dinas Kesehatan Provinsi Bali, 2018). Berdasarkan data Dinas Kesehatan Provinsi Bali prevalensi kasus hipertensi pada lansia terbanyak pada tahun 2018 ada di Kabupaten Tabanan, dengan jumlah sebanyak 4376 kasus (12,20\%), ke dua Kota Denpasar sebanyak 4289 kasus (11,96\%), ke tiga Kabupaten Buleleng sebanyak 4221 kasus (11,77\%) ke empat Kabupaten Gianyar sebanyak 4081 (11,20\%). Menurut data yang diperoleh dari Dinas Kesehatan Kabupaten Gianyar angka kejadian pada kasus hipertensi pada lansia di Kabupaten Gianyar terus mengalami peningkatan yang signifikan daripada kabupaten lainnya di Provinsi Bali. Angka kejadian pada kasus hipertensi pada lansia di Kabupaten Gianyar tahun 2016 sebanyak 2137 kasus, tahun 2017 meningkat menjadi 3566 kasus dan tahun 2018 sebanyak 4081 kasus. Jumlah lansia hipertensi tahun 2018 paling banyak terdapat di Wilayah Kerja Puskesmas Gianyar II dengan jumlah kasus sebanyak 310 lansia menderita hipertensi dan terbanyak berasal dari Desa Angkling sebanyak 54 orang (Dinas Kesehatan Kabupaten Gianyar, 2018).

Dampak kerugian-kerugian yang diderita apabila seseorang terserang hipertensi dan penyakit-penyakit yang ditimbulkannya sangat luas. Dari sisi ekonomi, setidaknya terdapat dua kelompok kerugian yang dialami penderita. Pertama adalah kerugian ekonomi yang terbagi menjadi empat bagian, yaitu dampak penyakit terhadap konsumsi sehat, interaksi sosial, produktivitas jangka pendek dan produktivitas jangka panjang.. Kehadiran hipertensi pada kelompok lansia sangat membebani perekonomian keluarga, karena biaya pengobatan yang mahal dan membutuhkan waktu yang panjang, bahkan seumur hidup (Anna \& Bryan, 2015). Pemerintah telah melakukan berbagai upaya untuk mewujudkan lansia sehat, mandiri, berkualitas dan produktif melalui kegiatan Pos Pelayanan Terpadu (Posyandu) Lanjut Usia atau Pos Pembinaan Terpadu (Posbindu) dan program Bina Keluarga Lansia (BKL) (Departemen Kesehatan Republik Indonesia, 2016).

Penanganan hipertensi dapat dilakukan dengan terapi komplementer. Beberapa contoh terapi komplementer keperawatan yang dapat diberikan untuk pasien hipertensi yaitu; terapi herbal, musik, yoga, akupuntur dan meditasi (Fuad, 2016). Meditasi digunakan pada penderita hipertensi karena dapat menurunkan hipertensi dengan mengontrol kontriksi dan merelaksasi pembuluh darah yang terletak pada pusat vasomotor di medula spinalis. Meditasi sendiri yang dapat digunakan adalah latihan relaksasi meditasi yang dapat menurunkan hipertensi sistolik kurang lebih $20 \mathrm{mmHG}$ dan diastolik kurang lebih 10-15 mmHg (Suryani, 2015). Meditasi mempunyai banyak keuntungan bagi kesehatan, diantaranya menurunkan tekanan darah dengan teknik memperbaki kondisi stres dan menghilangkan masalah psikososial. Hal ini penting karena stress dan permasalahan psikososial akan menyebabkan aktivitas saraf simpatik yang menyebabkan tekanan darah meningkat (Jeri, 2015). Hasil penelitian Rohaedi, Putri, dan Karimah (2016) menemukan bahwa meditasi berpengaruh terhadap penurunan stres dan psikososial pada lansia dengan hipertensi primer di Panti Sosia Tresna Werdha Yogyakarta. Penelitian Widodo dan Purwaningsih (2013) menemukan bahwa meditasi berpengaruh signifikan terhadap kualitas hidup lansia 
Bali Medika Jurnal.

Vol 8 No 1, 2021: 51-63

DOI: https://doi.org/10.36376/bmj.v8i1

yang menderita hipertensi di Unit Rehabilitasi Sosial Wening Wardoyo Ungaran Kabupaten Semarang.

Berdasarkan studi pendahuluan yang peneliti lakukan pada bulan April 2019 di Posyandu Lansia di Desa Bakbakan Banjar Angkling pada 10 orang lansia hipertensi, diperoleh informasi bahwa aktivitas perawatan diri lansia hipertensi menggunakan terapi nonfarmakologis (90\%) lebih sering dari pada terapi farmakologis anti hipertensi (10\%). Beberapa terapi nonfarmakologis yang dilakukan yaitu; terapi herbal menggunakan mentimun, air kelapa dan jus mengkudu serta obat obat dari Puskesmas. Aktivitas perawatan diri terhadap penyakit hipertensi melalui terapi nonfarmakologis dilakukan hanya ketika pasien hipertensi merasakan gejala seperti pusing dan nyeri tengkuk atau saat pasien mengetahui tekanan darahnya melebihi batas normal saat pemeriksaan di Puskesmas. Hasil wawancara kepada 10 pasien hipertensi, pemanfaatan terapi nonfarmakologi alasannya karena lebih mudah dan murah.

Upaya yang dilakukan oleh puskesmas Gianyar II untuk meningkatkan kesejahteraan dan kesehatan lansia melalui kegiatan posyandu lansia. Kegiatan yang dilakukan di posyandu lansia seperti pemeriksaan kesehatan, olahraga dan penyuluhan. Desa bakbakan Banjar Angkling sudah memiliki posyandu lansia yang diselenggarakan setiap 2 minggu sekali kegiatan yang diberikan kepada lansia terutama yang menderita hipertensi meliputi pemeriksaan kesehatan, penyuluhan tentang hipertensi dan senam. Kegiatan posyandu lansia belum sepenuhnya diikuti oleh lansia di Desa Bakbakan Banjar Angkling karena tingkat kehadiran lansia masih dibawah 50\% dengan rata-rata kehadiran lansia sebanyak 30 orang dari 78 orang lansia yang terdapat di Desa Bakbakan Banjar Angkling.

Gambaran aktivitas perawatan diri pasien hipertensi dan upaya yang dilakukan oleh pihak Puskesmas Gianyar II melalui kegiatan posyandu lansia ternyata masih belum dapat menyelesaikan masalah hipertensi. Hal ini dibuktikan dengan jumlah kasus lansia hipertensi di Banjar Angkling desa Bakbakan semakin meningkat yang dari tahun 2017 sebanyak 38 lansia menjadi sebanyak 54 lansia di tahun 2018.

Penelitian ini bertujuan untuk menganalisa pengaruh meditasi terhadap tekanan darah. Manfaat penelitian ini adalah memberikan terapi meditasi sebagai salah satu penatalaksanaan yang dapat mempengaruhi tekanan darah. Berdasarkan latar belakang diatas, maka peneliti tertarik untuk melaksanakan penelitian tentang pengaruh pemberian meditasi terhadap hipertensi pada lansia di Banjar Angkling Desa Bakbakan Wilayah Kerja Puskesmas Gianyar II.

\section{METODE PENELITIAN}

Jenis penelitian ini adalah pra eksperimental dengan rancangan Pra eksperimen One group Pre test-posttest Design. Penelitian ini telah dilaksanakan di Banjar Angkling Desa Bakbakan wilayah kerja Puskesmas Gianyar II. Sampel dalam penelitian ini adalah lansia dengan hipertensi di Banjar Angkling Desa Bakbakan wilayah kerja Puskesmas Gianyar II. Sampel dalam penelitian ini ditentukan berdasarkan kriteria inklusi penelitian ini adalah lansia berusia $\geq 60$ tahun, memiliki riwayat hipertensi primer. Kriteria eksklusi adalah yang memiliki komplikasi akibat menderita hipertensi seperti penyakit jantung, ginjal dan lain- 
lain. Jumlah sampel sebanyak 20 orang. Tehnik sampling yang digunakan adalah Purposive Sampling. Variabel independen dalam penelitian ini adalah meditasi. Variabel dependen dalam penelitian ini adalah hipertensi..

Prosedur analisis dalam penelitian ini proses pengolahan data mengikuti langkah - langkah sebagai berikut editing, coding, entri data dan cleaning atau tabulasi. Analisa data pada penelitian ini mengunakan uji "Paired t test". Penentuan hipotesis diterima atau ditolak apabila nilai probability lebih kecil dari nilai signifikansi $(\mathrm{p}<0,05)$ maka ada pengaruh pemberian meditasi terhadap hipertensi pada lansia di Banjar Angkling Desa Bakbakan Wilayah Kerja Puskesmas Gianyar II.

\section{HASIL DAN PEMBAHASAN}

1. Umur

\section{Tabel 4.1}

Distribusi Responden Berdasarkan Umur di Banjar Angkling Desa Bakbakan Wilayah Kerja Puskesmas Gianyar II Tahun 2019

\begin{tabular}{clc}
\hline No & Umur & Hasil \\
\hline 1 & Mean & 69,35 \\
\hline 2 & Minimum & 65,00 \\
\hline 3 & Maksimum & 74,00 \\
\hline 4 & SD & 3,27 \\
\hline
\end{tabular}

Berdasarkan tabel 4.1 menunjukkan karakteristik berdasarkan umur rata-rata berumur 69,35 tahun, umur minimum 65 tahun dan umur maksimum 74 tahun.

2. Jenis kelamin

Tabel 4.2

Distribusi Frekuensi Responden Berdasarkan Jenis Kelamin di Banjar Angkling Desa Bakbakan Wilayah Kerja Puskesmas Gianyar II Tahun 2019

\begin{tabular}{clcc}
\hline No & Jenis Kelamin & Frekuensi & Persentase $(\%)$ \\
\hline 1 & Laki-laki & 8 & 40,00 \\
\hline 2 & Perempuan & 12 & 60,00 \\
\hline & Total $(\mathrm{N})$ & 20 & 100,00 \\
\hline
\end{tabular}

Berdasarkan tabel 4.2 menunjukkan responden terbanyak berjenis kelamin perempuan sebanyak 12 orang, dengan persentase $60 \%$.

3. Pendidikan

Tabel 4.3

Distribusi Frekuensi Responden Berdasarkan Pendidikan di Banjar Angkling Desa Bakbakan Wilayah Kerja Puskesmas Gianyar II Tahun 2019

\begin{tabular}{clcc}
\hline No & Pendidikan & Frekuensi & Persentase (\%) \\
\hline 1 & SD & 1 & 5,00 \\
\hline 2 & SMP & 5 & 25,00 \\
\hline 3 & SMA & 14 & 70,00 \\
\hline & Total $(\mathrm{N})$ & 20 & 100,00 \\
\hline
\end{tabular}


Bali Medika Jurnal.

Vol 8 No 1, 2021: 51-63

ISSN : 2615-7047

DOI: https://doi.org/10.36376/bmj.v8i1

Berdasarkan tabel 4.3 menunjukkan responden terbanyak tamat SMA sebanyak 14 orang, dengan persentase $70 \%$.

\section{Hasil pengamatan terhadap variabel penelitian}

1. Tekanan darah lansia dengan hipertensi sebelum pemberian meditasi

\begin{tabular}{llcccc}
\hline Tekanan Darah & Mean & Median & Minimal & Maksimal & SD \\
\hline Sistole & 169,25 & 170 & 160 & 180 & 6,74 \\
\hline Diastole & 101,75 & 100 & 90 & 115 & 6,54 \\
\hline
\end{tabular}

Berdasarkan tabel 4.5 menunjukkan rata-rata tekanan darah sistole lansia dengan hipertensi sebelum pemberian meditasi adalah $169,25 \mathrm{mmHg}$ dengan nilai minimum $160 \mathrm{mmHg}$ dan maximum $180 \mathrm{mmHg}$. Rata-rata tekanan darah diastole adalah 101,75 mmHg dengan nilai minimum $90 \mathrm{mmHg}$ dan maximum $115 \mathrm{mmHg}$. Rata-rata tekanan darah sistole dan diastole sebelum pemberian meditasi termasuk kategori hipertensi grade II.

2. Tekanan darah lansia dengan hipertensi setelah pemberian meditasi

\begin{tabular}{llcccc}
\hline Tekanan Darah & Mean & Median & Min & Max & SD \\
\hline Sistole & 139,75 & 140 & 120 & 150 & 6,78 \\
\hline Diastole & 75,95 & 76,50 & 60 & 90 & 8,73 \\
\hline
\end{tabular}

Berdasarkan tabel 4.6 menunjukkan rata-rata tekanan darah sistole lansia dengan hipertensi setelah pemberian meditasi adalah $139,75 \mathrm{mmHg}$ dengan nilai minimum $120 \mathrm{mmHg}$ dan maksimum $150 \mathrm{mmHg}$. Rata-rata tekanan darah diastole adalah 75,95 mmHg dengan nilai minimum $60 \mathrm{mmHg}$ dan maksimum $90 \mathrm{mmHg}$. Rata-rata tekanan darah sistole dan diastole setelah pemberian meditasi termasuk kategori normal tinggi.

\section{Hasil Analisis Data}

Tabel 4.7

Hasil Analisis Pengaruh Pemberian Meditasi Terhadap Hipertensi Pada Lansia di Banjar Angkling Desa Bakbakan Wilayah Kerja Puskesmas Gianyar II

Tahun 2019

\begin{tabular}{|c|c|c|c|c|}
\hline Tekanan Darah & Mean & Selisih mean & $p$ value & $Z_{\text {hitung }}$ \\
\hline Sistole Pre Test & 169,25 & \multirow{2}{*}{29,50} & \multirow{2}{*}{0.00} & \multirow{2}{*}{3,94} \\
\hline Sistole Post Test & 139,75 & & & \\
\hline Diastole Pre Test & 101,75 & \multirow{2}{*}{25,80} & \multirow{2}{*}{0.00} & \multirow{2}{*}{3,93} \\
\hline Diastole Post Test & 75,95 & & & \\
\hline
\end{tabular}

Berdasarkan hasil uji statistik Paired t Test didapatkan nilai Zhitung sistole $=$ 3,94 $>$ Znormal $=1,96$ dan $p$ value $=0,00<\alpha 0,05$, nilai Zhitun diastole $=3,93>$ Znormal $=1,96$ dan $p$ value $=0,00<\alpha 0,05$ menunjukkan ada pengaruh pemberian meditasi terhadap hipertensi pada lansia di Banjar Angkling Desa Bakbakan Wilayah Kerja Puskesmas Gianyar II, selain itu dapat dilihat adanya penurunan skor tekanan darah sistole sebelum dan sesudah pemberian meditasi sebesar 29,50 $\mathrm{mmHg}$ dan penurunan skor tekanan diastole sebesar $25,80 \mathrm{mmHg}$ yang menunjukkan adanya penurunan tekanan darah. 
Bali Medika Jurnal.

Vol 8 No 1, 2021: 51-63

ISSN : 2615-7047

DOI: https://doi.org/10.36376/bmj.v8i1

\section{Tekanan Darah Lansia Dengan Hipertensi Sebelum Pemberian Meditasi}

Hasil penelitian menunjukan rata-rata tekanan darah sistole lansia dengan hipertensi sebelum pemberian meditasi adalah $169,25 \mathrm{mmHg}$ dengan nilai minimum $160 \mathrm{mmHg}$ dan maximum $180 \mathrm{mmHg}$. Rata-rata tekanan darah diastole adalah 101,75 mmHg dengan nilai minimum $90 \mathrm{mmHg}$ dan maximum $115 \mathrm{mmHg}$. Rata-rata tekanan darah sistole dan diastole sebelum pemberian meditasi termasuk kategori hipertensi grade II. Berdasarkan klasifikasi hipertensi dari Guideline Joint National Committee (JNC) delapan, hasil penelitian ini menunjukkan responden menderita hipertensi derajat II. Menurut Ardiansyah (2016) hipertensi menjadi masalah pada usia lanjut karena sering ditemukan dan menjadi lebih dari separuh kematian diatas usia 60 tahun disebabkan oleh penyakit jantung dan serebrovaskuler.

Hasil penelitian ini juga didukung oleh teori Ardiansyah (2016) hipertensi merupakan penyakit multifaktorial yang munculnya oleh karena interaksi berbagai faktor salah satunya stres dapat menjadi penyebab timbulnya hipertensi dimana terjadi sel-sel saraf yang mengakibatkan kelainan pengeluaran atau pengangkutan natrium. Hubungan antara stres dan hipertensi diduga melalui aktivitas saraf simpatis (saraf yang bekerja ketika beraktivitas) yang dapat meningkatkan tekanan darah secara bertahap. Menurut Ardiansyah (2016) salah satu faktor penyebab hipertensi adalah pola makan tinggi garam yang dapat meningkatkan sekresi hormon natriuretik yang secara tidak langsung akan meningkatkan tekanan darah. Intake sodium juga akan menstimulasi mekanisme vasopresor di sistem saraf pusat. Selain itu, Martin (2017) mengatakan kurangnya aktivitas fisik merupakan salah satu penyebab hipertensi, kurang aktivitas fisik menjadikan daya pompa jantung kurang optimal. Sehingga aliran darah dalam tubuh tidak lancar. Kurangnya aktifitas fisik meningkatkan risiko menderita hipertensi karena meningkatkan risiko kelebihan berat badan. Orang yang tidak aktif juga cenderung mempunyai frekuensi denyut jantung yang lebih tinggi sehingga otot jantungnya harus nbekerja lebih keras pada setiap kontraksi. Makin keras dan sering otot jantung harus memompa, makin besar tekanan yang dibebankan pada arteri.

Hipertensi yang dialami dipengaruhi oleh faktor jenis kelamin. Responden dalam penelitian ini sebagian besar perempuan, menurut Junaidi (2017) penyakit hipertensi cenderung lebih tinggi pada jenis kelamin perempuan dibandingkan dengan laki-laki,. Wanita yang belum mengalami menopause dilindungi oleh hormon estrogen yang berperan dalam meningkatkan kadar High Density Lipoprotein (HDL). Kadar kolesterol HDL yang tinggi merupakan faktor perlindung dalam mencegah terjadinya proses aterosklerosis. Efek perlindungan estrogen dianggap sebagai penjelasan adanya imunitas wanita pada usia premenopause. Pada pramenopause wanita mulai kehilangan sedikit demi sedikit hormon estrogen yang selama ini melindungi pembuluh darah dari kerusakan. Proses ini terus berlanjut dimana hormon estrogen tersebut berubah kuantitasnya sesuai dengan umur wanita secara alami, yang umumnya mulai terjadi pada wanita diatas 45 tahun.

Faktor lain yang memengaruhi derajat hipertensi adalah usia. Responden dalam penelitian ini rata-rata berumur 69.35 tahun. Menurut Triyanto (2016) kejadian hipertensi semakin meningkat seiring dengan bertambahnya umur. Hipertensi biasanya muncul pada umur 60 tahun ke atas, dengan bertambahnya 
Bali Medika Jurnal.

Vol 8 No 1, 2021: 51-63

DOI: https://doi.org/10.36376/bmj.v8i1

umur, maka tekanan darah juga akan meningkat karena dinding arteri akan mengalami penebalan oleh karena adanya penumpukan zat kolagen pada lapisan otot, sehingga pembuluh darah akan berangsur-angsur menyempit dan menjadi kaku. Tekanan darah diastolik meningkat sampai dekade kelima dan keenam kemudian menetap atau cenderung menurun. Peningkatan umur akan menyebabkan beberapa perubahan fisiologis yaitu terjadi peningkatan resistensi perifer.

Faktor pendidikan juga dapat mempengaruhi kejadian hipertensi, karakteristik responden berdasarkan pendidikan menunjukkan sebagian besar tamat SMA, hal ini disebabkan karena orang yang memiliki tingkat pendidikan tinggi diduga memiliki pengetahuan yang lebih baik serta tinggal di kota besar sehingga mempermudah akses terhadap pangan tetapi mereka tidak mengetahui tentang kandungan makanan yang mereka konsumsi, misalnya makanan sea food, junk food dan jenis makanan yang mengandung banyak kolesterol yang beresiko menyebabkan hipertensi. Konsumsi pangan berlebih (khususnya pangan berisiko) diduga berhubungan dengan peningkatan tekanan darah (Ardiansyah, 2016).

Hasil penelitian yang didapat, didukung oleh penelitian yang dilakukan oleh Pujiastuti (2016) tentang pengaruh pemberian meditasi terhadap penurunan tekanan darah penderita hipertensi di Desa Sindumartani Ngemplak Sleman Yogyakarta. Hasil penelitian ini didapatkan rata-rata tekanan darah sistole pre-test rata-rata $162,17 \mathrm{mmHg}$ dan tekanan darah diastole rata-rata 98,10mmHg termasuk katagori hipertensi tahap 2. Hasil penelitian yang didapat juga didukung oleh penelitian yang dilakukan oleh Gunawan (2016) tentang pengaruh meditasi terhadap penurunan tekanan darah pada populasi lansia dengan hipertensi esensial di Gunungkidul, Yogyakarta. Hasil penelitian ini didapatkan rata-rata tekanan darah sistole pre-test rata-rata $167,20 \mathrm{mmHg}$ dan tekanan darah diastole rata-rata 99,05 $\mathrm{mmHg}$ termasuk katagori hipertensi tahap 2.

Peneliti berpendapat, sebagian besar responden pada penelitian ini menderita hipertensi dalam kategori hipertensi tahap 2 hal ini dapat disebabkan karena lansia kurang melakukan aktivitas fisik. Kurangnya aktifitas fisik meningkatkan risiko menderita hipertensi karena meningkatkan risiko kelebihan berat badan. Orang yang tidak aktif juga cenderung mempunyai frekuensi denyut jantung yang lebih tinggi sehingga otot jantungnya harus bekerja lebih keras pada setiap kontraksi. Makin keras dan sering otot jantung harus memompa, makin besar tekanan yang dibebankan pada arteri. Menurut peneliti faktor pemicu responden terkena hipertensi selaian karena kurang melakukan aktivitas fisik juga disebabkan mengkonsumsi garam natrium yang berlebih dan kurangnya aktivitas olahraga serta dari faktor resiko yang tidak dapat dikontrol karena bertambahnya usia mereka. Hal ini sesuai fakta yang peneliti temui di lapangan, lansia yang menjadi responden pada penelitian ini mengatakan biasa mengkonsumsi makanan yang lebih asin disebabkan karena jika makan makanan yang kurang asin tidak terasa dan hambar, hal ini dipengaruhi perubahan fisiologis lansia pada indera pengecap, hal ini menyebabkan lansia di Banjar Angkling Desa Bakbakan Wilayah Kerja Puskesmas Gianyar II banyak yang menderita hipertensi.

\section{Tekanan Darah Lansia Dengan Hipertensi Setelah Pemberian Meditasi}

Hasil penelitian menunjukan rata-rata tekanan darah sistole lansia dengan hipertensi setelah pemberian meditasi adalah $139,75 \mathrm{mmHg}$ dengan nilai minimum 
Bali Medika Jurnal.

Vol 8 No 1, 2021: 51-63

DOI: https://doi.org/10.36376/bmj.v8i1

$120 \mathrm{mmHg}$ dan maksimum $150 \mathrm{mmHg}$. Rata-rata tekanan darah diastole adalah 75,95 mmHg dengan nilai minimum $60 \mathrm{mmHg}$ dan maksimum $90 \mathrm{mmHg}$. Ratarata tekanan darah sistole dan diastole setelah pemberian meditasi termasuk kategori normal tinggi. Rata-rata tekanan darah sistole dan diastole setelah pemberian meditasi termasuk kategori normal tinggi. Terjadinya penurunan tekanan darah setelah responden melakukan yoga pranayama, hal ini sesuai dengan teori Jeri (2015) meditasi dapat digunakan pada penderita hipertensi karena dapat menurunkan hipertensi dengan mengontrol kontriksi dan merelaksasi pembuluh darah yang terletak pada pusat vasomotor di medula spinalis.

Menurut Suryani (2015), secara umum latihan relaksasi meditasi dapat menurunkan tekanan darah tinggi sistolik lebih dari $20 \mathrm{mmHg}$ dan diastolik $10-15$ $\mathrm{mmHg}$. Penurunan ini disebabkan karena relaksasi meditasi pada prinsipnya adalah memposisikan tubuh dalam kondisi tenang, sehingga akan mengalami relaksasi dan pada akhirnya akan mengalami kondisi keseimbangan, dengan demikian relaksasi meditasi yang berintikan pada pernafasan akan meningkatkan sirkulasi oksigen ke otot-otot, sehingga otot-otot akan mengendur, tekanan darah akan menurun.

Hasil penelitian yang didapat didukung oleh penelitian sebelumnya yang dilakukan oleh Martin (2017) tentang pengaruh terapi meditasi terhadap perubahan tekanan darah pada lansia yang mengalami hipertensi. Hasil penelitian menunjukkan nilai rata-rata pre test sebesar $162,35 / 96,72 \mathrm{mmHg}$ menjadi $132,78 / 77,81 \mathrm{mmHg}$ saat post test. Hasil penelitian yang didapat juga didukung oleh penelitian sebelumnya yang dilakukan Sudiarto (2017) tentang pengaruh terapi relaksasi meditasi terhadap penurunan tekanan darah pada lansia dengan hipertensi. Hasil penelitian menunjukkan nilai rata-rata pre test sebesar 158,12/98,20 $\mathrm{mmHg}$ menjadi 141,22/80,01 mmHg saat post test. Penelitian Fuad (2016) tentang pengaruh meditasi garuda terhadap tekanan darahdan gejala hipertensi pada pasien hipertensi usia pertengahan di Desa Balung Lor Kecamatan Balung Kabupaten Jember. Hasil penelitian menunjukkan nilai rata-rata pre test sebesar 164,15/98,76 mmHg menjadi 134,08/80,11 $\mathrm{mmHg}$ saat post test.

Menurut peneliti meditasi, yang merupakan salah satu aktivitas fisik yang berfungsi untuk penyelarasan pikiran, jiwa dan fisik seseorang. Meditasi adalah sebuah aktivitas dimana seseorang memusatkan seluruh pikiran untuk mengontrol panca indra dan tubuhnya secara keseluruhan. Meditasi memberikan manfaat bagi kesehatan tubuh, kekuatan maupun vitalitas. Obat penenang alami yang diproduksi otak yang melahirkan rasa nyaman dan meningkatkan kadar endorphin dalam tubuh untuk mengurangi tekanan darah tinggi.

\section{Pengaruh Pemberian Meditasi Terhadap Hipertensi Pada Lansia}

Berdasarkan hasil uji statistik Paired t Test didapatkan nilai Zhitung sistole $=$ 3,94 $>$ Znormal $=1,96$ dan $\mathrm{p}$ value $=0,00<\alpha 0,05$, nilai Zhitun diastole $=3,93>$ Znormal $=1,96$ dan $p$ value $=0,00<\alpha 0,05$ menunjukkan ada pengaruh pemberian meditasi terhadap hipertensi pada lansia di Banjar Angkling Desa Bakbakan Wilayah Kerja Puskesmas Gianyar II, selain itu dapat dilihat adanya penurunan skor tekanan darah sistole sebelum dan sesudah pemberian meditasi sebesar 29,50 $\mathrm{mmHg}$ dan penurunan skor tekanan diastole sebesar $25,80 \mathrm{mmHg}$ yang menunjukkan adanya penurunan tekanan darah. Hasil penelitian ini sesuai dengan teori Guyton dan Hall (2015) meditasi memberikan efek vasodilatasi pembuluh 
Bali Medika Jurnal.

Vol 8 No 1, 2021: 51-63

DOI: https://doi.org/10.36376/bmj.v8i1

darah, peningkatan oksigenasi jaringan dan menurunkan stres yang menjadi faktor pencetus keparahan hipertensi. Efek vasodilatasi dan penurunan rangsang simpatis dapat meningkatkan aliran oksigen menjadi lebih lancar. Perangsangan saraf simpatis dan parasimpatis memberikan efek pada pembuluh darah sistemik dan tekanan arteri. Sebagian besar pembuluh darah sistemik akan berkontriksi bila ada perangsangan saraf simpatis.

Menurut Dusek dan Benson (2015) mengemukakan bahwa respon relaksasi erat kaitannya dengan axis Hipothalamus-Pituitary- Adrenal (HPA). Seseorang dalam keadaan relaksasi, axis HPA ini akan menurunkan kadar kortisol, epineprin dan noreprineprin yang dapat menyebabkan penurunan tekanan darah dan frekuensi nadi. Kadar kortisol dalam darah berefek dalam vasokontriksi pembuluh darah. Penurunan kadar epineprin dan norepineprin dapat menyebabkan vasodilatasi pembuluh darah. Kadar epineprin dan noreprineprin dalam darah bekerja langsung di reseptor andregenik alfa otot polos vaskular, sehingga menyebabkan vasokonstriksi. Vasodilatasi pembuluh darah yang disebabkan oleh penurunan kadar epineprin dan norepineprin ini dapat menurunkan tahan perifer total yang akan menurunkan tekanan darah.

Penelitian yang dilakukan oleh Martin (2017) tentang pengaruh terapi meditasi terhadap perubahan tekanan darah pada lansia yang mengalami hipertensi. terapi meditasi selama 15 menit dilakukan 3 kali selama seminggu. Hasil penelitian menunjukkan adanya pengaruh secara signifikan pemberian meditasi untuk untuk tekanan darah pada lansia menderita hipertensi. Penelitian Marthayoga (2014) pengaruh meditasi terhadap tekanan darah pada orang hipertensi di Desa Bungbungan Kecamatan Banjarangkan Klungkung. Latihan meditasi selama 3 hari tiap latihan selama 30 menit. Hasil penelitian menunjukkan ada perbedaan tekanan darah pada kelompok perlakuan setelah dilatih meditasi. Penelitian yang dilakukan oleh Sudiarto (2017) pengaruh terapi relaksasi meditasi terhadap penurunan tekanan darah pada lansia dengan hipertensi di wilayah Binaan Rumah Sakit Emanuel Kelampok Banjarnegara. Tekhnik relaksasi meditasi yang dilakukan selama satu bulan dengan lama latihan 2 x 15 menit dengan frekuensi 3 kali seminggu. Hasil penelitian menunjukkan ada pengaruh terapi relaksasi meditasi terhadap penurunan tekanan darah pada lansia dengan hipertensi.

Menurut peneliti, meditasi berpengaruh terhadap tekanan darah pada lansia dengan hipertensi karena pernapasan mempunyai kaitan yang erat dengan pikiran. Perasaan atau emosi produk dari pikiran. Hal ini akan tampak pada seseorang yang sedang marah, karena pikirannya tidak tenang, tidak berjalan dengan harmonis, maka napasnya pun menjadi kacau. Orang yang dalam keadaan sedih, cemas, takut, atau sedang panik nafasnya tidak berjalan dengan teratur. Meditasi bisa menjadi salah satu alternatif bagi pasien hipertensi, dengan meditasi pasien akan lebih mampu menghilangkan atau mengurangi stress, dimana dengan melakukan meditasi akan menghasilkan respon stress sehingga aksi hipotalamus menyesuaikan dan terjadi penurunan aktivitas sistem saraf simpatis sehingga tekanan darah akan menurun.

Hasil penelitian ini menunjukkan tekanan diastole mengalami penurunan lebih banyak dibandingkan dengan penelitian-penelitian sebelumnya, menurut peneliti hal ini disebabkan meditasi dalam intervensi keperawatan dikatakan sebagai salah satu tehnik nafas dalam yang benar dan panjang. Pernapasan dalam 
Bali Medika Jurnal.

Vol 8 No 1, 2021: 51-63

DOI: https://doi.org/10.36376/bmj.v8i1

membuat tubuh lebih mudah mendapatkan oksigen yang dibutuhkan untuk proses metabolisme secara efisien. Teknik pernapasan yang tepat sangat penting, sehingga dapat meningkatkatkan energi, mampu membakar lemak, dan membantu melancarkan sirkulasi dalam darah. Jantung akan mendapat keuntungan bekerja lebih efisien, yaitu memompa darah lebih banyak dengan denyutan lebih jarang, menurunkan kadar lemak dalam darah, misalnya kalesterol dan trigliseride, sehingga bahaya pengendapan lemak pada dinding pembuluh darah dapat dikurangi sehingga kemungkinan tersumbatnya pembuluh darah yang menuju otot jantung akan berkurang dan menurunkan tekanan darah diastole.

Menurut peneliti penurunan tekanan darah pada lansia setelah melakukan meditasi dapat dipengaruhi oleh motivasi lansia dalam mengikuti meditasi, hal ini dibuktikan tingkat kehadiran lansia selama penelitian semuanya datang sesuai jadwal yang telah ditentukan. Selama pemberian meditasi lansia terlihat sangat menikmati proses pelaksanaan meditasi serta nampak senang sehingga hal tersebut mempengaruhi hormon endorpine yang membuat lansia menjadi rileks saat melakukan meditasi sehingga hal tersebut memicu penurunan tekanan darah.

\section{SIMPULAN DAN SARAN}

Hasil penelitian menunjukkan ada pengaruh pemberian meditasi terhadap hipertensi pada lansia di Banjar Angkling Desa Bakbakan Wilayah Kerja Puskesmas Gianyar II. Meditasi dapat digunakan sebagai pendukung dari pengobatan nonfarmakologis untuk menurunkan tekanan darah pada lansia yang menderita hipertensi, terapi dengan meditasi sebagai intervensi untuk menurunkan tekanan darah sehingga dapat meningkatkan status kesehatan lansia. Keterbatasan pada penelitian ini adalah variabel perancu dalam penelitian ini belum dapat dikontrol dengan baik, meskipun sudah dikontrol melalui kriteria inklusi tetapi seperti latar belakang pendidikan pada lansia belum dibuat homogen dalam penelitian ini.

\section{UCAPAN TERIMA KASIH}

Peneliti mengucapkan terima kasih kepada Puskesmas Gianyar II atas ijin yang diberikan untuk pengambilan data dan melakukan intervensi pada lansia di wilayah kerja puskesmas.

\section{DAFTAR PUSTAKA}

Anna, \& Bryan. (2015). Simple Guide Tekanan Darah Tinggi. Jakarta: Erlangga.

Ardiansyah. (2016). Medikal Bedah Untuk Mahasiswa. Yogyakarta: DIVA Press.

Badan Pusat Statistik. (2018). Profil Penduduk Menurut Usia. Retrieved July 12, 2019, from bps.go.id website: https://www.bps.go.id

Black, J. M., \& Hawks, J. N. (2015). Medical Surgical Nursing vol 2 (7th ed.). China: Elsevier Saunders.

Departemen Kesehatan Republik Indonesia. (2016). Pedoman Puskesmas Santun Lanjut 
Bali Medika Jurnal.

Vol 8 No 1, 2021: 51-63

ISSN : 2615-7047

DOI: https://doi.org/10.36376/bmj.v8i1

Usia Bagi Petugas Kesehatan. Jakarta: Direktorat Bina Kesehatan Komunitas.

Dinas Kesehatan Kabupaten Gianyar. (2018). Profil Kesehatan Kabupaten Gianyar 2018. Gianyar: Dinas Kesehatan Kabupaten Gianyar.

Dinas Kesehatan Provinsi Bali. (2018). Laporan Tahunan Data Kesehatan Provinsi Bali. Denpasar: Bagian Pencatatan dan pelaporan Dinas Kesehatan Provinsi Bali.

Dusek, J. A., \& Benson, H. (2015). Mind Body Medicine; A Model of The Comparative Clinical Impact Of The Acute Stress And Relaxation Responded. Minnesota Medical Association, 92(5).

Fuad, N. (2016). Pengaruh Meditasi Garuda Terhadap Tekanan Darahdan Gejala Hipertensi pada Pasien Hipertensi Usia Pertengahan di Desa Balung Lor Kecamatan Balung Kabupaten Jember. Jurnal Ners Indonesia, 1(2).

Gunawan. (2016). Pengaruh Meditasi Terhadap Penurunan Tekanan Darah Pada Populasi Lansia dengan Hipertensi Esensial di Gunungkidul, Yogyakarta. Jurnal IPTEKS Terapan Research Of Applied Science And Education, 10(4).

Guyton, \& Hall. (2015). Fisiologi Kedokteran. Jakarta: EGC.

Jeri, H. (2015). Pengaruh pemberian Meditasi Terhadap Penurunan Tekanan Darah pada Lansia dengan Hipertensi di Unit Sosial Rehabilitasi Pucang Gading Semarang. Jurnal Keperawatan, 2(2).

Junaidi, I. (2017). Hipertensi Pengenalan, Pencegahan, dan Pengobatan. Jakarta: Bhuana Ilmu Populer.

Kementerian Kesehatan Republik Indonesia. (2018). Riset Kesehatan Dasar. Jakarta: Badan Penelitian dan Pengembangan Kesehatan.

Marthayoga. (2014). Pengaruh Meditasi Terhadap Tekanan Darah pada Orang Hipertensi di Desa Bungbungan Kecamatan Banjarangkan Klungkung. Jurnal Skala Medika, $3(2)$.

Martin, W. (2017). Pengaruh Terapi Meditasi Terhadap Perubahan Tekanan Darah pada Lansia yang Mengalami Hipertensi di Wilayah Kerja Puskesmas Pembantu Tabek Gadang Kecamatan Aur Birugo Tigo Baleh. Jurnal IPTEKS Terapan, 10(2).

Pujiastuti, T. (2016). Pengaruh Pemberian Meditasi Terhadap Penurunan Tekanan Darah Penderita Hipertensi di Desa Sindumartani Ngemplak Sleman Yogyakarta. Journal Keperawatan Soedirman, 2(3).

Rohaedi, S., Putri, S. T., \& Karimah, A. D. (2016). Tingkat Kemandirian Lansia Dalam Activities Daily Living Di Panti Sosial Tresna Werdha Senja Rawi. Pendidikan Keperawatan Indonesia, 2(1), 17.

Sudiarto. (2017). Pengaruh Terapi Relaksasi Meditasi Terhadap Penurunan Tekanan Darah pada Lansia dengan Hipertensi di Wilayah Binaan Rumah Sakit Emanuel Klampok Banjarnegara. The Soedirman Journal of Nursing, 2(3).

Suryani, L. K. (2015). Menemukan Jati Diri Dengan Meditasi. Jakarta: Elex Media Komputindo.

Tamher, \& Noorkasiani. (2015). Kesehatan Usia Lanjut dengan Pendekatan. Asuhan Keperawatan. Jakarta: Salemba Medika. 
Bali Medika Jurnal.

Vol 8 No 1, 2021: 51-63

ISSN : 2615-7047

DOI: https://doi.org/10.36376/bmj.v8i1

Triyanto. (2016). Pelayanan Keperawatan Bagi Penderita Hipertensi Secara Terpadu. Jakarta: Graha Ilmu.

Widodo, G. G., \& Purwaningsih, P. (2013). Pengaruh Meditasi terhadap Kualitas Hidup Lansia yang Menderita Hipertensi di Unit Rehabilitasi Sosial Wening Wardoyo Ungaran Kabupaten Semarang. Jurnal Keperawatan Medikal Bedah, 1(2). 